\title{
Food Adulteration in Switzerland: From 'Ravioli' over 'Springbok' to 'Disco Sushi'
}

\author{
Philipp Hubner* \\ In commemoration of our colleague and friend Rolf Etter (1951-2015), Kantonschemiker Zürich
}

\begin{abstract}
The driving force behind food adulteration is monetary profit and this has remained unchanged for at least the last hundred years. Food adulterations were and still are difficult to uncover because they occur mostly in an unpredictable and unexpected way. Very often food falsifiers take advantage of modern technology in such a way that food adulterations are difficult or sometimes even impossible to detect. Targets for food adulteration were and still are highly priced food items such as spirits, meat, seafood and olive oil. Although difficult to detect, food adulterations were in the past strong driving forces for the development of adequate detection methods in the official food control laboratories and for the enforcement of the food law. A very prominent example in this context is the 'Ravioli scandal' in Switzerland in the late 1970s which showed that cheap second-class meat could be processed into products without being discovered for long time. As a consequence the official food control laboratories in Switzerland were reinforced with more laboratory equipment and technical staff. With the introduction of new detection principles such as DNA-based analytical methods new kinds of food adulteration could and can be uncovered. Analytical methods have their limits and in some cases of food fraud there are no analytical means to detect them. In such cases the examination of trade by checking of accounts is the method of choice.
\end{abstract}

Keywords: Checking of accounts $\cdot$ Food adulteration $\cdot$ Meat adulteration $\cdot$ Ravioli scandal $\cdot$ Sushi adulteration

\section{Introduction}

To give a historical overview of food adulteration in Switzerland is a nearly impossible task. A small booklet published 1910 with the title 'Foodstuff and the Art of Fakery' (Nahrungsmittel und Fälscherkünste, ${ }^{[1]}$ Fig. 1) was an unexpected aid in indicating that the driving force for food adulteration has remained unchanged for at least the last hundred years: monetary profit. In the booklet's preface is stated that "every person has the right to receive from the seller what he asks and pays for, even when the buyer usually has no possibility to examine the bought items. However, very often this assumption is wrong, as can be shown by numerous articles in the newspapers reporting penalization of foodstuff falsifiers. Considering that only a vanishingly small proportion of foodstuff falsifiers is caught due to the still not rigorously organised control systems you might be horrified by the notion how many undiscovered sins are dished up to ordinary mortals and what you have to consume as a normal person. The difficulty

${ }^{*}$ Correspondence: Dr. P. Hubner, Kantonschemiker Kantonales Laboratorium Basel Kannenfeldstrasse 2, CH-4012 Basel

E-mail: philipp.huebner@bs.ch to uncover subtle falsifications is directly related to the frequency of occurrence of manipulations which are illegally undertaken with foodstuffs".

(Original German text: "Jeder Mensch hat das Anrecht darauf, das, was er verlangt und bezahlt, vom Verkäufer $z u$ erhalten, auch wenn dem Käufer, wie es in den meisten Fällen zutrifft, die Möglichkeit fehlt, das Gekaufte zu prüfen. Wie sehr gegen diese allgemeine Voraussetzung gefehlt wird, zeigen die in allen Tageszeitungen immer wieder auftauchenden Berichte über Bestrafung von Nahrungsmittelfälschern. Bedenkt man, dass doch nur ein verschwindend kleiner Teil von Nahrungsmittelfälschern bei den immer noch nicht durchgreifend organisierten Kontrollsystemen ertappt wird, so kann man ein kleines Grauen bei der Vorstellung bekommen, wieviel unentdeckte Sünden dem gewöhnlich Sterblichen mit dem aufgetischt wird, was er als irdisches Geschöpf verzehren muss. Die Schwierigkeit, raffinierte Verfälschungen zu finden, ist hierbei der direkte Ausdruck für die Häufigkeit der Manipulationen, die in unberechtigter Weise mit den Nahrungs- und Genussmitteln vorgenommen werden".)

In order to detect food adulterations it is important that the corresponding food item is characterised as fully as possible and legally defined. It is in this context not surprising that the cited booklet contains many tables describing various food items in great detail. Although the topic of

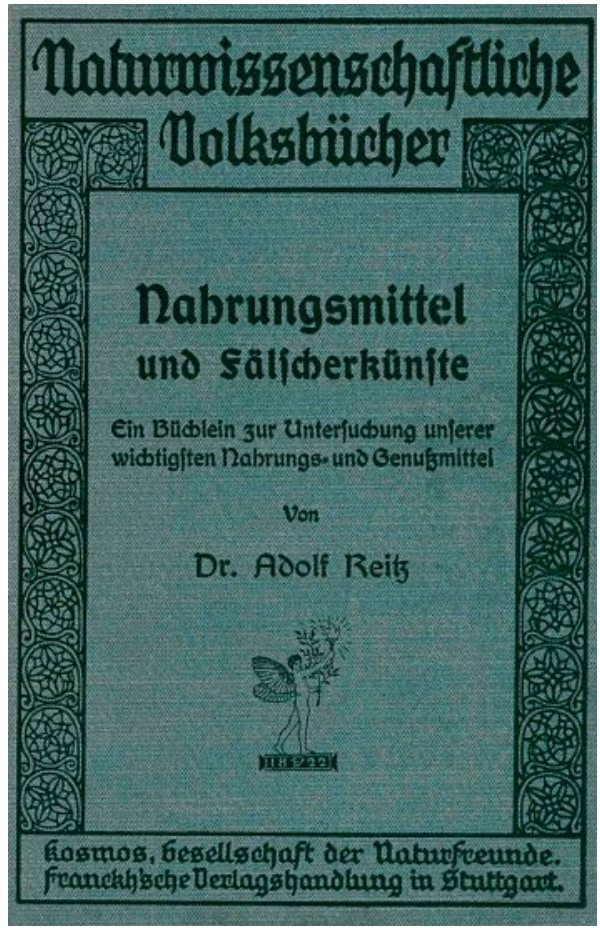

Fig. 1. The booklet with the title 'Foodstuff and the Art of Fakery' (Nahrungsmittel und Fälscherkünste) was published in 1910 in Stuttgart, Germany. Its content is still valid although the analytical techniques have changed a lot in the mean time! 
food adulteration has remained unchanged for 100 years the analytical methods have changed enormously. For instance the cited booklet describes differences between German red wines due to specific weight, alcohol content, extract, total acidity and so on (Fig. 2) whereas modern methods use the isotopic distribution for discrimination of wines (see e.g. article by Rossier in this issue $\left.{ }^{[2]}\right)$.

In the following sections some examples of food adulterations in Switzerland from the past four decades are presented.

\section{Ravioli Scandal}

In 1978 the well-known Swiss TV consumer program 'Kassensturz' reported on a ravioli test by the Swiss Foundation for Consumer Protection filmed in the style of an secret agent thriller. ${ }^{[3]}$ Canned ravioli were at that time bestsellers and were especially popular with families. However, their composition was mainly unknown until that remarkable broadcast of 'Kassensturz'. The test revealed that for some products the meat percentage was very low and sometimes the meat was of dubious quality. 'Kassensturz' headlined that the testers even found stomach, heart, kidneys, pancreas, lungs and pig heads in some ravioli. Of course, these animal ingredients were shown in the broadcast together with a pig's head. This broadcast was a real eye-opener for viewers.

As a consequence producers of canned ravioli recorded losses in sales. They criticised that the broadcast gave the impression ravioli were inferior in general and not just some of the products tested. Two companies sued the television company. In the first instance, the court dismissed the case in 1982. The court stated that the broadcast

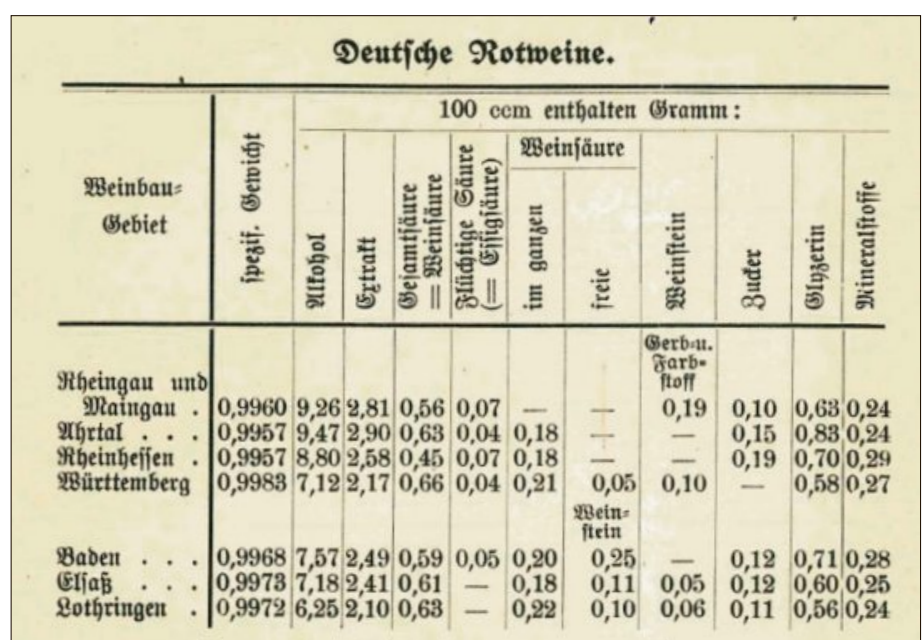

Fig. 2. 100-yearold analytical table with parameters for analytical differentiation of German red wine varieties. In the meantime Elsass and Lothringen belong to France, but wine is still a target for food adulteration!

represented an expert investigation and a tolerable product criticism. Nevertheless, the Swiss TV agreed a few months later to a settlement. It was noted that the Swiss TV had in no way intended to give the impression that the products manufactured by the complainant companies were inferior or unappetizing.

A further consequence of the ravioli scandal was that the public awareness for food adulteration changed dramatically and the work of the official food control bodies in Switzerland was more carefully observed than ever. Further, people started to read the list of ingredients!

And finally Swiss families stopped eating canned ravioli.

\section{Bacardi Adulteration ... or what you get at the bar is not always what you expect}

Due to a tip from a former employee a big discotheque was suspected of adulterating trademark spirituous beverages.
Original flasks of Bacardi, Jack Daniels whiskey and tequila were equipped with dispensers and were used for the open bar next to sealed original flasks stored on the racks. In the bar, everything made a correct impression. The competent food inspection service was asked to take samples from the sealed original flasks and from the bottles with the dispenser. In the laboratory both Bacardi samples were analysed for higher alcohols and flavourings without a significant difference being observed (Table 1). The only difference was that ethyl acetate was present in 10-fold higher concentration in the original bottle. However, this difference alone was not sufficient to prove a food adulteration. The brilliant idea was that if spirits are adulterated, this would be done with water from the local water supply, which has its own ion pattern. The measured anion pattern indeed revealed significant differences between the opened and the closed Bacardi bottles. ${ }^{[4]}$ The adulterator had probably thought of the volatile aroma components and the higher alcohols, but not of the ion patterns!

Table 1. Analytical differentiation between original Bacardi and Bacardi sampled from the bar. The main difference is the anion pattern due to use of water from the local water supply. n.d.: not detected.

\begin{tabular}{|c|c|c|c|c|c|c|c|c|c|c|c|c|c|c|}
\hline Parameter & 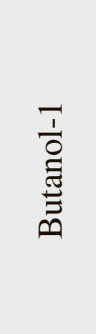 & 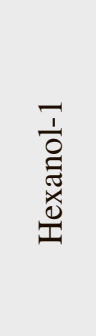 & 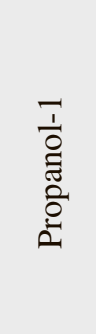 & $\begin{array}{c}\frac{1}{O} \\
\stackrel{\Xi}{\Xi} \\
\stackrel{\Xi}{\Xi} \\
ض\end{array}$ & 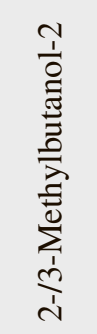 & 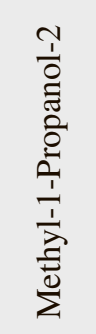 & 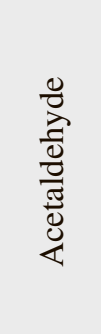 & 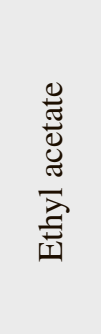 & 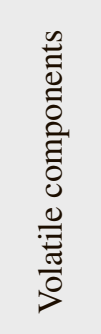 & $\begin{array}{l}\frac{\infty}{0} \\
\frac{0}{0} \\
\frac{0}{\pi} \\
\bar{\Xi} \\
\frac{0}{00} \\
. \bar{I}\end{array}$ & 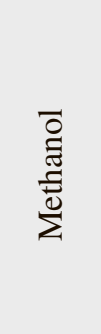 & $\frac{\frac{0}{0}}{\frac{0}{0}}$ & $\underset{\stackrel{\Xi}{\Xi}}{\stackrel{\Xi}{\Xi}}$ & $\frac{\stackrel{\Xi}{\Xi}}{\stackrel{\Xi}{\Xi}}$ \\
\hline unit & $\begin{array}{l}\mathrm{mg} / \mathrm{L} \\
\mathrm{EtOH}\end{array}$ & $\begin{array}{l}\mathrm{mg} / \mathrm{L} \\
\mathrm{EtOH}\end{array}$ & $\begin{array}{l}\mathrm{mg} / \mathrm{L} \\
\mathrm{EtOH}\end{array}$ & $\begin{array}{l}\mathrm{mg} / \mathrm{L} \\
\mathrm{EtOH}\end{array}$ & $\begin{array}{l}\mathrm{mg} / \mathrm{L} \\
\mathrm{EtOH}\end{array}$ & $\begin{array}{l}\mathrm{mg} / \mathrm{L} \\
\mathrm{EtOH}\end{array}$ & $\begin{array}{l}\mathrm{mg} / \mathrm{L} \\
\mathrm{EtOH}\end{array}$ & $\begin{array}{l}\mathrm{mg} / \mathrm{L} \\
\mathrm{EtOH}\end{array}$ & $\begin{array}{l}\mathrm{mg} / \mathrm{L} \\
\mathrm{EtOH}\end{array}$ & $\begin{array}{l}\mathrm{mg} / \mathrm{L} \\
\mathrm{EtOH}\end{array}$ & $\begin{array}{l}\mathrm{mg} / \mathrm{L} \\
\mathrm{EtOH}\end{array}$ & $\mathrm{mg} / \mathrm{L}$ & $\mathrm{mg} / \mathrm{L}$ & $\mathrm{mg} / \mathrm{L}$ \\
\hline $\begin{array}{c}\text { original } \\
\text { Bacardi bottle }\end{array}$ & 3 & n.d. & 87 & n.d. & 220 & 61 & 46 & 67 & 486 & 284 & 14 & 1 & 0 & 2 \\
\hline $\begin{array}{c}\text { Bacardi from } \\
\text { the Bar }\end{array}$ & n.d. & n.d. & 57 & n.d. & 157 & 44 & 20 & 7 & 289 & 202 & 12 & 3 & 2 & 14 \\
\hline
\end{tabular}


When the manager was confronted with the analytical results, he admitted having bought alcohol for drinking purposes together with Bacardi flavour and having mixed the two components with drinking water from the local water supply. The already opened original containers were systematically refilled with adulterated Bacardi stored behind the bar (Fig. 3 ). The manager proceeded in a similar fashion with Jack Daniels whiskey and tequila. Interestingly the operating manager could readily order specific flavours with an Austrian flavour company together with the instructions for reconstitution.

\section{Roe Deer or Springbok?}

Venison often is prepared with acidic wine and herbs, which leads to special aroma compounds (Wildpfeffer). Although processed venison has a distinct taste the processing per se hampered in the past the analytical differentiation of the different venison species based on isoelectric focusing (IEF). With the introduction of DNA-based detection methods such as polymerase chain reaction (PCR) the species differentiation of processed venison became feasible. The introduction of this detection technology initially led to many cases of adulterated venison until the falsifiers realised that the official food control bodies are able to detect this kind of food adulteration. At that time often high priced roe deer (Reh) meat was the target of adulteration with cheaper types of venison, sometimes even from species from Africa. DNA sequencing technology helped to identify suspicious venison samples with high accuracy without the need to analyse corresponding reference samples. For instance, our laboratory analysed 1999 about 30 game meat samples. ${ }^{[5]}$ Interestingly, the processed venison samples were often found to be inhomogeneous. Therefore several small pieces from a sample were analysed. Four samples were found to be adulterated. In a roe deer sample we found pieces of red deer, in another roe deer sample there were pieces of red deer and Muntiak, a deer species from Asia. A chamois sample contained pieces of sheep and red deer. Finally we found a roe deer sample which contained meat from an animal which was at that time not yet in the DNA database. The highest homology was found with springbok from Africa. A year later we found again many foreign animal species in venison samples (Table 2).

\section{Disco Sushi}

Fresh tuna is characterised by its red meat which becomes an unsightly brown
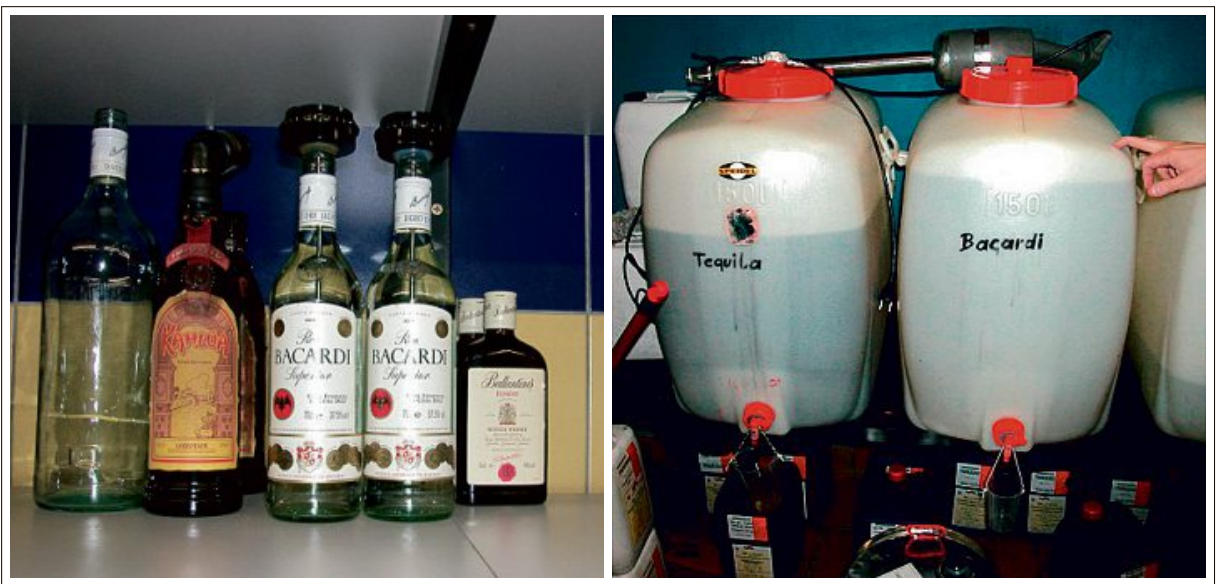

Fig. 3. Left: Bacardi displayed in the bar; right: Bacardi stored behind the bar.

Table 2. Identification of venison species by DNA sequencing technology. The best fits from the DNA databank search (Blast search) are given for adulterated venison samples. The homology to the best fit species and to the labelled species is given in $\%$.

\begin{tabular}{|l|l|c|c|}
\hline $\begin{array}{l}\text { Venison } \\
\text { labelled as }\end{array}$ & $\begin{array}{l}\text { 'Best fit' from } \\
\text { Blast search }\end{array}$ & $\begin{array}{c}\text { Homology with } \\
\text { the 'Best fit' }\end{array}$ & $\begin{array}{c}\text { Homology to } \\
\text { the labelled } \\
\text { species }\end{array}$ \\
\hline Capreolus capreolus & Cervus elaphus & $99.5 \%$ & $89.1 \%$ \\
\hline Capreolus capreolus & Muntiacus muntjak & $99.8 \%$ & $90.4 \%$ \\
\hline Rupicapra rupicapra & Ovis aries & $99.3 \%$ & $88.9 \%$ \\
\hline Sus scrofa fera & Capreolus capreolus & $100 \%$ & $90.1 \%$ \\
\hline Capreolus capreolus & Nemorhas & $99.3 \%$ & $88.7 \%$ \\
\hline Capreolus capreolus & Gazella gazella & $98.2 \%$ & $86.4 \%$ \\
\hline
\end{tabular}

colour in the course of aging. In order to stabilise the red colour in some countries tuna was treated with carbon monoxide or with filtered tasteless smoke. Since this colour stabilization is not influenced by spoilage consumers could be deceived regarding the freshness of the product. In addition, spoiled tuna is known to contain high amounts of histamine which might provoke adverse reactions in consumers. For import into Switzerland each consignment of meat and meat products must be accompanied by an official certificate of consumption suitability issued by the competent authority of the country of origin. The health certificate for the importation of fish and fish products was at that time complemented with a provision explicitly excluding treatment with carbon monoxide or a tasteless smoke. Carbon monoxide strongly binds to $\mathrm{Fe}^{2+}$ chelated by the heme group of myoglobin stabilizing its oxidation status and thus the red colour. Furthermore the oxidation by oxygen to $\mathrm{Fe}^{3+}$ is strongly decelerated. In 2005 more than $20 \%$ of the controlled tuna samples had to be rejected due to illegal treatment with CO. In January 2006 the border veterinarians at the customs offices at Zurich
Airport and at Geneva Airport took samples from suspicious tuna shipments from the Philippines. Since the samples displayed a striking unnatural red colour they were forwarded to our laboratory for examination of illegal treatment with carbon monoxide. Since we could not detect any treatment with $\mathrm{CO}$ we assumed a treatment with red dye. During the subsequent analysis the dyes rhodamine B dye and yellow orange $\mathrm{S}$ were found in the three suspicious samples. ${ }^{[6]}$ Rhodamine B is not approved in Switzerland for food or cosmetics. Since rhodamine B is a fluorescent dye which lights up under UV light the control at the border was very easy. Equipped with an UV lamp the border veterinarians could identify the adulterated tuna samples on the spot. In the lab slang this sample was called 'disco sushi' (Fig. 4).

\section{(Swiss) German Chicken}

Food adulterations cannot always be detected by analytical means. In 2004 the official food control body of canton Aargau was informed that a well-known chicken meat producer was suspected of importing 


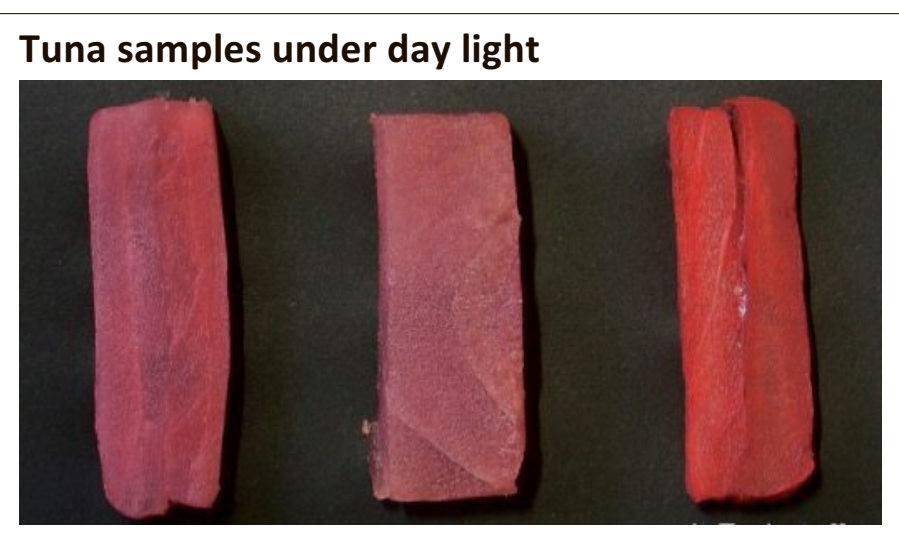

Tuna samples under UV $366 \mathrm{~nm}$ light

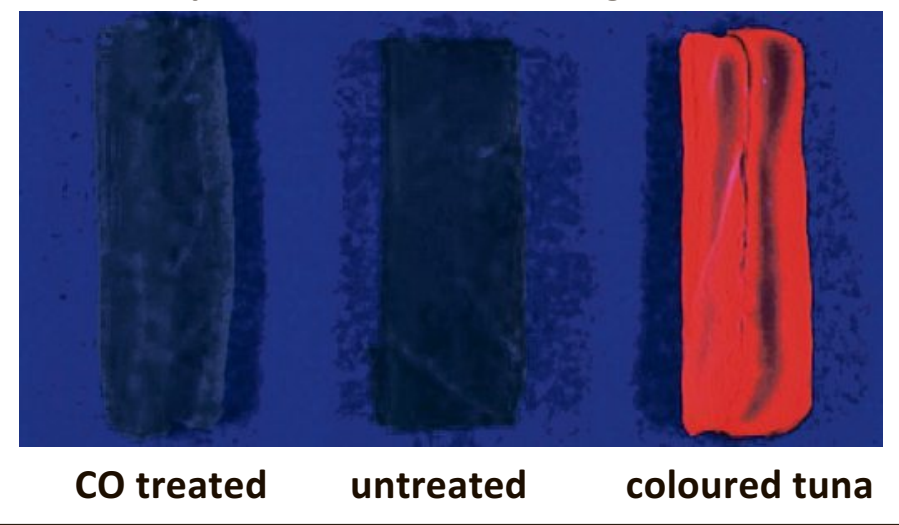

chicken meat from Germany and selling it as Swiss chicken meat. There is probably no analytical technique available to distinguish between German and Swiss chicken meat! Thus, the food inspection service controlled the books of the incriminated company and found that in November and December 2004 a total of 1'100 kg high quality chicken breast fillet were imported from Germany. $240 \mathrm{~kg}$ of this meat were correctly sold as German chicken breast fillet. $720 \mathrm{~kg}$ of this chicken meat were stored frozen in portions of $500 \mathrm{~g}$ labelled as cut chicken breast Switzerland. However, this batch was blocked since a labelling mistake seems to have happened. The official food control body confiscated this meat. For the missing $140 \mathrm{~kg}$ chicken meat there were no available papers to trace its fate.
Fig. 4. 'Disco Sushi'. Top: CO treated, untreated and coloured tuna samples in standard light. Bottom: the same three samples under UV $366 \mathrm{~nm}$ light. The Disco Sushi sample lights up!

Since there was the suspicion that this food adulteration had taken place over many years the food control authority of Aargau re-examined the company's records for the years 2001 to 2004. A total of 300 tons of chicken and turkey meat were imported from Germany. After processing (removal of skin and bones, filleting, repacking) 230 tons remained, which were sold as Swiss meat. ${ }^{[7]}$ The price difference between German and Swiss chicken meat at that time was $3 \mathrm{CHF} / \mathrm{kg}$. Altogether the unjustified profit amounted to 700'000 CHF! From a total volume of sales of 13 '400 tons, $1.7 \%$ was not correctly labelled and the case went to the court. The responsible person was sentenced to 6 months prison and a fine of 10'000 CHF. In addition 200'000 CHF of the illegal profit had to be reimbursed to the state.

\section{Conclusion}

Since the driving force for food adulteration is mainly monetary profit, often high-value food items such as wine, spirits, meat, seafood and olive oil are targeted. Mostly food adulterations were and still are difficult to detect because they are often unpredictable and unexpected. Thus, hunting for the unpredictable and unexpected often is the key factor for successful discovery of food adulteration by official food control authorities. The good message is that there is more than enough work for all of us; the bad message is that we will often be one step behind the food falsifier if we do not start to think as they do! And keep in mind that analytical methods have their limits and in some cases of food fraud there are no analytical means to detect them. In such cases the examination of trade by checking of accounts is the method of choice. Good and close collaboration between food analysts and food inspectors is the most powerful tool in the fight against food adulteration.

Received: December 30, 2015

[1] A. Reitz, 'Nahrungsmittel und Fälscherkünste', Kosmos, Gesellschaft der Naturfreunde, Stuttgart, 1910.

[2] J. S. Rossier, V. Maury, L. Gaillard, E. Pfammater, Chimia 2016, 70, 338.

[3] http://www.srf.ch/konsum/themen/serien/40 jahre-kassensturz/die-lebensmittel-skandale\#

[4] Jahresbericht Kantonales Amt für Lebensmittelkontrolle St. Gallen, 2003.

[5] Jahresbericht Kantonales Laboratorium BaselStadt, 1999.

[6] Jahresbericht Kantonales Laboratorium BaselStadt, 2006.

[7] Jahresbericht Kantonales Labor Aargau, 2005. 